\title{
Carotid Arteries in the Dog: Structure and Histophysiology
}

\author{
Arterias Carótidas en el Perro: Estructura e Histofisiología \\ ${ }^{*, * *}$ Antonio M. Orsi; *Raquel F. Domeniconi; ***Silvana Martinez B. Artoni \& *Joffre G. Filho
}

ORSI, M. A.; DOMENICONI, F. R.; ARTONI, B. S. M. \& G. FILHO, J. Carotid arteries in the dog: Structure and histophysiology. Int. J. Morphol., 24(2):239-244, 2006.

SUMMARY: Light microscopy analysis of the mural structure of the common carotid artery, internal carotid artery and external carotid artery in mongrel dog revealed variability in the middle values of vascular diameter and thickness of the intimal plus medial coats and adventitial coat. The vascular diameter did not differ between the internal carotid artery and external carotid artery, but was significantly increased in the common carotid artery from which the other two arteries had origin. The increased thickness of the intimal plus medial coats of the common carotid artery revealed the constant mechanical adjustment of the arterial wall and local shearing stress that occurred among the arterial coats. The adventitial coat of the internal carotid artery was significantly thicker than those of the common carotid and external carotid arteries, with no significant difference noted between the latter arteries. These histomorphometric results were related to the qualitative observations regarding the mural structure of the three arteries analyzed, especially regarding to the increased thickness and structural complexity of the adventitial coat of the internal carotid artery. Perhaps it acted as an external protective sheath of the vascular wall during its long course until the carotid channel.

KEY WORDS: Carotid arteries; Histology; Histophysiology; Dog.

\section{INTRODUCTION}

The common carotid arteries (CCA) of dog ended near a transverse plane passing throughout the hyoid bone body originating on the both sides the right and left external carotids (ECA) as well as the right and left internal carotid arteries (ICA). The ICA irrigated the brain, contributing to formation of the arterial circulation at the base of the brain (Puchades-Orts et al., 1976), while the ECA was considered the continuation of the CCA on the same side of the face in which it originated several branches related to the facial vasculature (Evans, 1993). Moreover, regarding to the histoarchitecture of some human elastic arteries including the CCA some studies had demonstrated variability in the thickness of the adventitial layer as well as local differences in the thickness of the complex formed by the intimal plus medial layers, mainly in regions subjected to small but expressive homodynamic stress (Willekes et al., 1999).

On the base these informations, this study aimed to analyse the angioarchitecture of the arterial wall focusing the histology of the layers that formed the CCA, ECA and ICA of dog. Thus, based on the histologic and histomorphometric analyses of these arteries concerning to the thickness of the intimal plus medial layers and adventitial layer, and also focusing the vascular diameter of each vessel, some histophysiologyc correlation was established, as was previously related for aortas of rabbit (Viegas et al., 2001), dog (Orsi et al., 2004), guinea pig and albino rat (Mello et al., 2004).

\section{MATERIAL AND METHOD}

Eight mongrel adult male dogs were studied after euthanasia with an overdose of anaesthetic formed by a mixture of ketamine hydrochloride $(20 \mathrm{mg} / \mathrm{kg})$ and xylazine hydrochloride $(1.5 \mathrm{mg} / \mathrm{kg})$. After cervical and thoracic dissections, fragments of the left common carotid artery (CCA), external carotid artery (ECA) and internal carotid artery (ICA) were collected and immediately fixed in $10 \%$ buffered formalin solution during 24 hours and processed to embedded in Paraplast ${ }^{\circledR}$ (Oxford Labware, St. Louis, USA).

* Departamento de Anatomia/UNESP, Campus de Botucatu, SP, Brasil.

** Setor de Anatomia/Faculdade de Medicina e Enfermagem - UNIMAR, Campus de Marília, SP, Brasil

**** Departamento de Morfologia e Fisiologia Animal/UNESP, Campus de Jaboticabal, SP, Brasil.

FAPESP, processo No $02 / 04127-0$. 
Sections of $5 \mu \mathrm{m}$ thicker were obtained and stained by hematoxylin-eosin, Masson's trichrome and Calleja's staining (Lillie, 1965). Ten selected slides of each artery were used for histomorphometric analysis, through a Computational Program of Image Analysis (Image Pro-Plus, Media Cybernetics, USA). During the analytic process 9 measurements per histologic section, of each vessel focused (CCA, ECA and ICA, respectively), were made for each one of the following parameters: (1) thickness of the intimal plus medial layers, (2) thickness of the adventitial layer and (3) vascular diameter using 3 sections by slide. The histomorphometric data of the thickness of the arterial layers as well as the vascular diameters were analysed statistically by repeated measuring multivariate analysis. Thickness of each layer and external vascular diameter were compared between the different vessels by the T Student test, at 0.05 of significance (Morrison, 1990).

\section{RESULTS}

Histomorphometric analysis. The histomorphometry of the mean thickness of the intimal plus medial layers and adventitial layer of the carotid arteries, e.g., common carotid artery (CCA), external carotid artery (ECA) and internal carotid artery (ICA), of dog showed that the conjunct intimal plus medial layers was thicker in the CCA comparatively to the same layer conjunct of the ICA and ECA. Although, no significant difference in the mean thickness of the intimal plus medial layer was observed between the ECA and ICA, because in both vessels the thickness of the coat coupling analysed presented similar middle values (Fig. 1). Concerning to the adventitial layer, it was significantly thicker in the ICA compared to the same layer of CCA and ECA. However, no significant difference was comparatively verified between the adventitial thickness of the CCA and ECA, respectively (Fig. 2). Concerning to the vascular diameter of the carotid arteries of dog, the largest mean value of vascular diameter was observed for the CCA, followed by the ICA with an intermediate diameter value. The ECA showed comparatively to the CCA and ICA the smallest middle diameter (Fig. 3). Furthermore, differences among the thickness of the three layers of the dog's carotid arteries were verified (Figs. 1 and 2).

Histologic analysis. Structurally the intimal layer of CCA, as in the other carotid vessels (ICA and ECA), showed a very thin pattern and appeared formed by endotheliocytes and internal elastic lamina (Figs. 4 and 5). The medial layer showed relative homogenous feature, because smooth muscle cells, connective fibres and lamellae, and other connective components, formed an interconnected meshwork intermingled with elastic fibres and thin elastic lamellae (Fig. 4), which had been a configuration more evident in elastic vessels as the CCA. In the adventitial structure of the CCA collagen and elastic fibres and lamellae with different spatial arrangements, e.g., with intermingled transverse, longitudinal and oblique dispositions were seen (Fig. 4), having a similar pattern in the adventitial layer of the ECA (Fig. 5) and ICA (Fig. 7). Also, an expressive number of small vessels and vasa-vasorum were seen into the adventitial structure of the CCA (Fig. 4), perhaps acting this coat as a vas conducting space of the arterial wall.

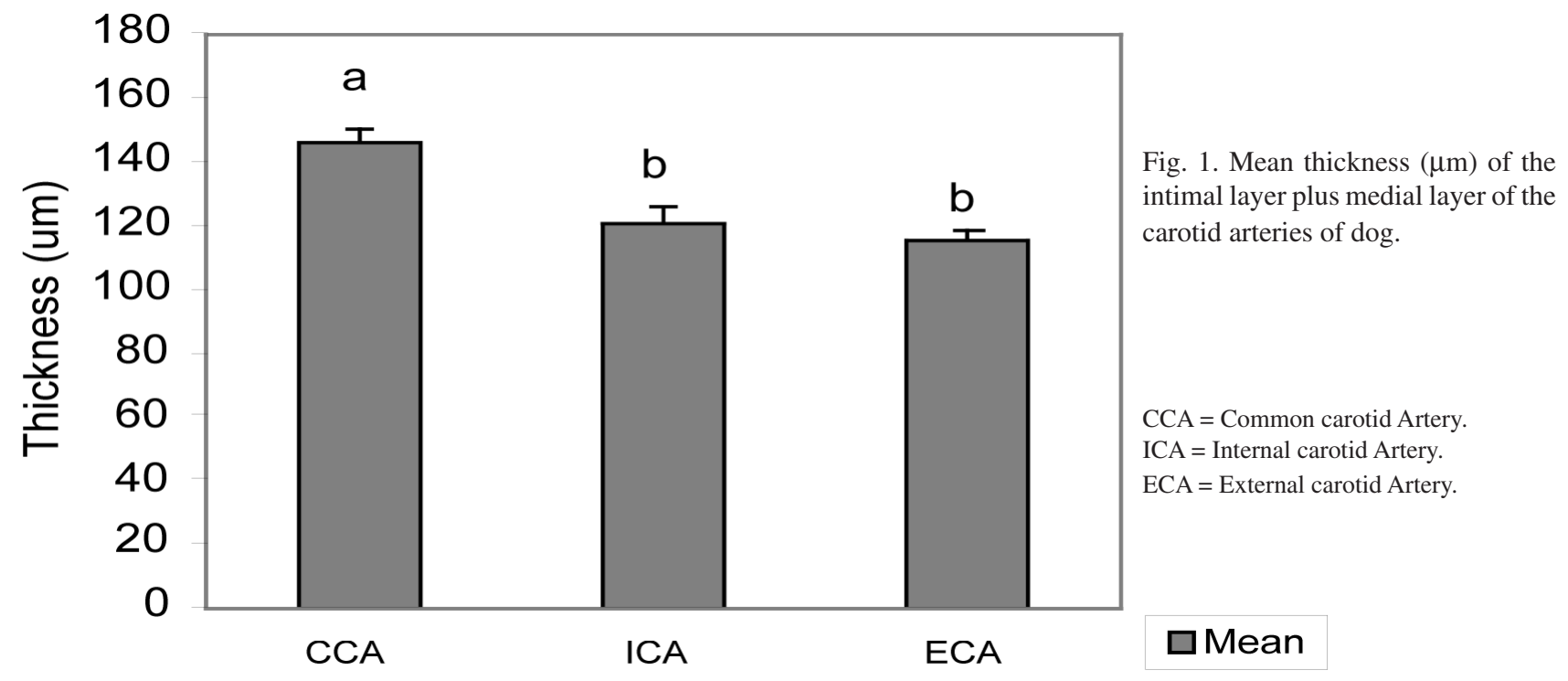




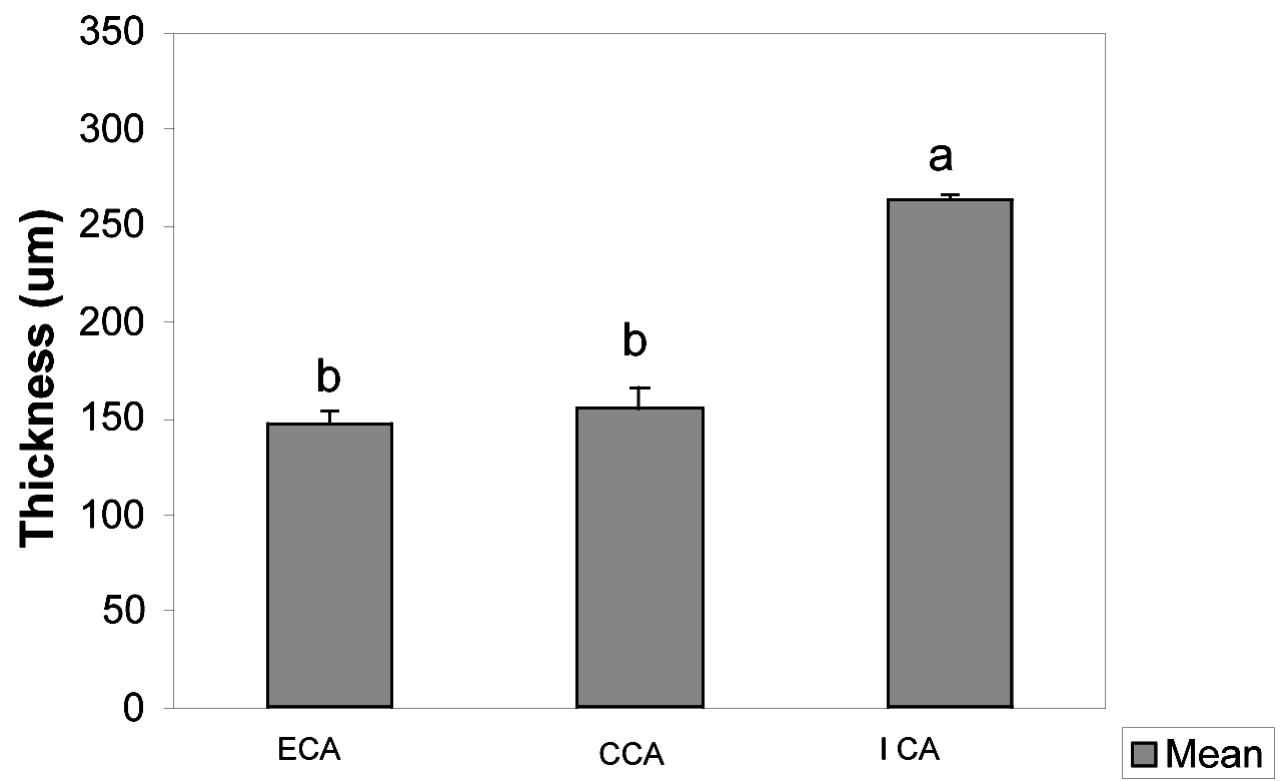

Fig. 2. Mean thickness $(\mu \mathrm{m})$ of the adventitial layer of the carotid arteries of dog.

$\mathrm{CCA}=$ Common carotid artery

ICA = Internal carotid artery.

$\mathrm{ECA}=$ External carotid artery.

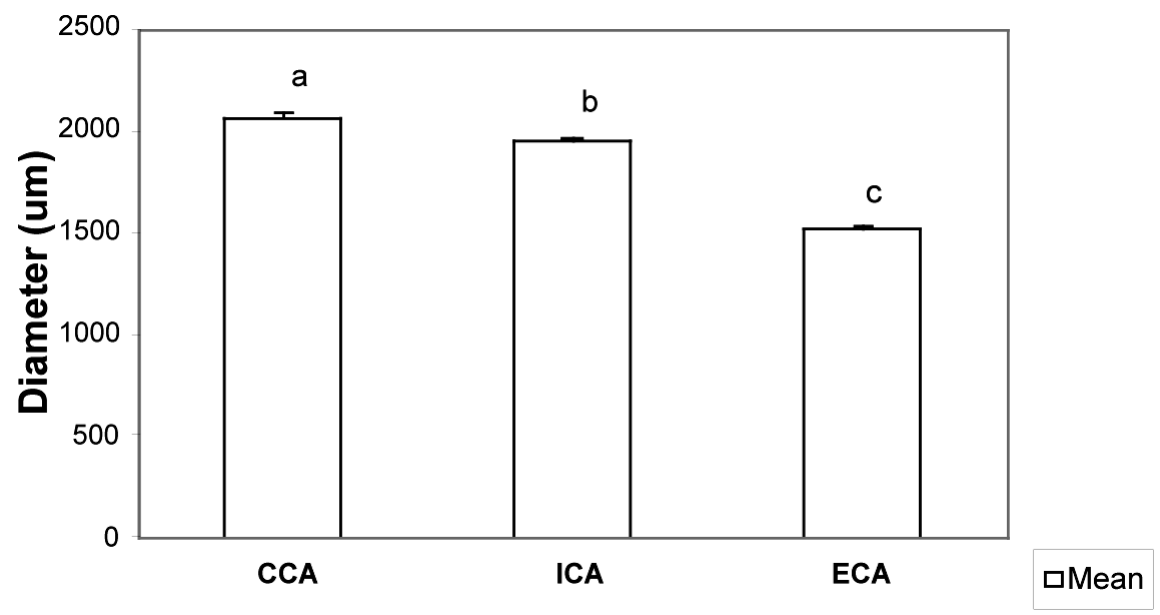

Fig. 3. Mean vascular diameter $(\mu \mathrm{m})$ of the carotid arteries of dog.

$\mathrm{CCA}=$ Common carotid artery. ICA $=$ Internal carotid artery. $\mathrm{ECA}=$ External carotid artery.

The histology of the ECA wall showed a pattern of a myoelastic vessel, presenting a mixed architecture. Smaller number of elastic lamellae with varied disposition interposed between collagen bundles and lesser amount of smooth muscle cells was seen at the medial layer structure (Figs. 5 and 6). Fusiform smooth muscle cells arranged in bundles intermingled with collagen predominated in the media, extending up to the intimal layer adjacent to the inner elastic lamina (Fig. 6). In the adventitial layer of the ECA, collagen bundles and lamellae, longitudinal elastic lamellae and collagen-elastic imbrications (Fig. 5) were verified. The general mural histoarchitecture of the ICA (Fig. 7) had a simi- lar pattern respect to that described for the ECA Nevertheless, the adventitial layer of the ICA besides to present the same variable arrangement of collagen and elastic fibres and lamellae, previous described for the CCA and ECA, showed a marked meshing among the stromal connective elements of the vascular wall (Fig. 7). Additionally, the adventitial layer of ICA was thicker than the same layer of CCA and ECA, respectively (see Fig. 2), perhaps forming an "external connective sheath" that acted as a protection for the vascular wall against boundary structures, during its long course from the cervical origin to the carotid channel, as will be discussed later. 

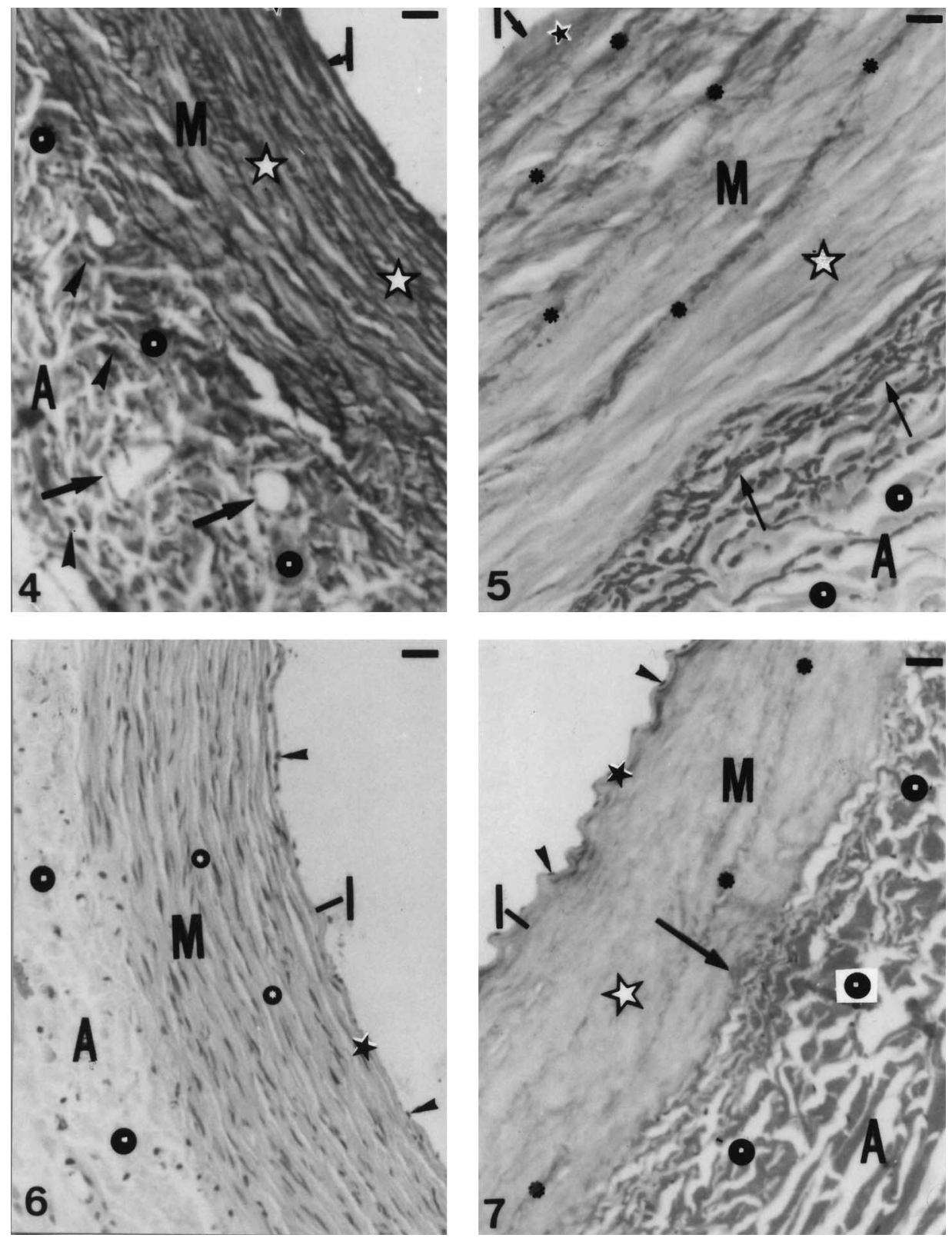

Figs. 4 to 7 . Histology of the wall of the carotid arteries in the dog showing the intimal (I), medial (M) and adventitial (A) layers in all the photomicrographs, and their details, being CCA in 4 (Masson's trichrome, scale bar $=5 \mu \mathrm{m})$; ECA in 5 (Calleja's trichrome, bar = $5 \mu \mathrm{m})$ and in $6(\mathrm{HE}$, bar $=12.5 \mu \mathrm{m})$ and ICA in 7 (Calleja's trichrome, bar $=5 \mu \mathrm{m})$.

The microscopic structures signalised were: endotheliocytes (small arrowheads) and inner elastic lamina (small stars) in I; myoconnective bundles (big star), elastic fibres and lamellae (small asterisks) with several dispositions - mainly transversal, and fusiform smooth muscle cells (small spheres) in $\mathrm{M}$; collagen fibres and lamellae (big spheres), blood vessels (middle arrows), elastic fibres and lamellae with transversal (big arrowhead) and longitudinal (small arrows) dispositions in $\mathrm{A}$, and presence of the outer elastic lamina (big arrow) in ICA (7).

\section{DISCUSSION}

The intimal layer of the wall of the carotid arteries (CCA, ECA and ICA), in the dog, appeared thin and formed by a single endothelial layer and by the inner elastic lamina. This general structure of the intimal layer had been described for different types of arteries, with some small variable characteristics such as occurrence of a more or less developed intimal musculature according to local functional specializations (Parke et al., 1995 and Kobayashi \& Sakai, 1997), which were not been verified for the carotid arteries of dog in this study.
Structural wall characteristics in dog's carotid arteries, especially found in the medial layer, revealed that the CCA was a typical elastic artery, while the ECA and ICA showed pattern of myoelastic vessels according to criteria proposed by Awal et al. (1995). This structural criteria was reviewed with concept of artery of transitional structure, noticed in the abdominal part of aorta em rodents (Mello et al.). Similarly to the aorta structure (Wolinsky \& Glagov, 1967; Song \& Roach, 1985; Viegas et al., 2001; Orsi et al. and Mello et al.), the observation of a large amount of elastic 
lamellae and fibres in the tunica media of the CCA in the dog, were related to a constant mechanical adjustment of the arterial wall as a consequence of a small, but conspicuous, variability noted in systolic and diastolic pressures of the left cardiac ventricle (Guyton, 1981, Mello et al.).

The increased thickness of the intimal plus medial layer complex observed in the CCA compared to the ECA and ICA in the dog could be theoretically related to the sliding of the mural coats and to the local hemodynamic stress on the vascular wall layers, as related for the human CCA (Willekes et al.). Our histomorphometric data confirmed the mural thickness increase of the intimal plus medial layers of the dog's CCA (Fig. 1).

Moreover, the medial layer in ECA and ICA in dog showed a myoelastic (transitional) histoarchitecture, having predominance of smooth muscle cells. Perhaps, these observations were related to some morphofunctional specialisations of the carotid vessels, which had been constantly subjected to local functional adaptations. Among them, were observed: (1) the emission of several collateral branches especially in the ECA (Evans); (2) occurrence of repeated foldings along the carotid arteries courses (Simionescu \& Simionescu, 1981), which had been related to cervical extension and flexion movements (Simionescu \& Simionescu and Evans), and, (3) the long and invasive inner course of the ICA between its origin from the CCA to its end at the level of the carotid channel located on the base of the skull.

Concerning to the architecture of the adventitial layer of the carotid arteries in the dog, an intermingled disposition of collagen fibres and lamellae with longitudinal, transverse and oblique arrangements was typically noted. Also the elastic fibres and lamellae showed a variable pattern, with an apparent predominance of longitudinal dispositions, followed by interrelations and connections between collagen and elastic fibres in the adventitial layer level. Presence of collagen-elastic connections and the different spatial arrangements of the connective fibres observed in the adventitial layer, respect to the elastic and myoelastic structures of the carotid arteries studied, perhaps help to guarantee the vascular wall integrity and protect the health condition of the arterial wall, as was similarly reported for the aorta structure in the own dog (Haas et al., 1991 and Orsi et al.).

ORSI, M. A.; DOMENICONI, F. R.; ARTONI, B. S. M. \& G. FILHO, J. Arterias carótidas en el perro: Estructura e histofisiología. Int. J. Morphol., 24(2):239-244, 2006.

RESUMEN: El análisis de la estructura de las arterias carótidas, común, externa y interna en el perro sin raza definida, a través del microscopio fotónico mostró variabilidad en los valores promedios de los parámetros: diámetro vascular y grosor de las capas íntima, media y adventicia de cada arteria, respectivamente. El diámetro vascular no difirió significantemente entre las arterias carótidas interna y externa, pero mostró aumento significativo en la arteria carótida común, la cual da origen a los dos otros vasos sanguíneos. El grosor aumentado de las capas íntima y media de la arteria carótida común, más directamente sometida a la fuerza de la presión sistólica cardiaca, significó los ajustes constantes de la pared vascular a las alteraciones de presión y al estrés de deslizamiento controlado entre las capas de la pared arterial. El grosor de la adventicia de la arteria carótida interna fue significativamente mayor que la de las otras arterias carótidas (común y externa), las cuales, entre, sí no tuvieron diferencia con respecto de la adventicia. Estos resultados morfométricos estaban directamente correlacionados con las observaciones morfológicas de naturaleza cualitativa, especialmente, en relación al incremento relativo de la adventicia de la carótida interna ya apreciable en las microfotografías. Tal vez, la adventicia en la arteria carótida interna actúa como una capa conjuntiva protectora, durante el complejo proceso de avance de esta arteria desde su origen cervical hasta el nivel del canal carotídeo donde alcanza la cavidad craneana.

PALABRAS CLAVE: Arterias carótidas; Histología; Histofisiología; Perro.

\section{REFERENCES}

Awal, M. A.; Matusomoto, M. \& Nishinakagawa, H. Morphometrical changes of the arterial wall of main arteries from heart to the abdomino-inguinal mammary glands of the rat from virgin to pregnancy. J. Vet. Med. Sci., 57:251-6, 1995.

Evans, H. E. Miller's Anatomy of the Dog. 3. ed. Philadelphia, Saunders, 1993.
Guyton, A. C. Tratado de Fisiologia Médica. Rio de Janeiro, Guanabara Koogan, 1981.

Haas, K. S.; Phillips, S. J.; Comerota, A. J. \& White, J.V. The architecture of adventitial elastin in the canine infrarenal aorta. Anat. Rec., 230:86-96, 1991.

Kobayashi, N.; Sakai, T. Emergence and distribution of 
intimal muscle cells in the postnatal rat aorta. Cell. Tiss. Res., 289: 487-97, 1997.

Lillie, R. D. Histopathologic technic and practical histochemistry. New York, McGrawHill, 1965.

Mello, J. M.; Orsi, A. M.; Padovani, C. R.; Matheus, S. M. M. \& Eleuterio, M. L. Structure of the aortic wall in the guinea pig and rat. Braz. J. Morphol. Sci., 21:35-8, 2004.

Morrison, D. F. Multivariate Statistical Methods. São PauloSP, Mc-Graw-Hill, 1990.

Orsi, A. M.; Stefanini, M. A.; Crocci, A. J.; Simões, K. \& Ribeiro, A. A. C. M. Some segmental features of the aortic wall of the dog. Anat. Histol. Embryol., 33:131-4, 2004.

Parke, W. W.; Whalen, J. L.; Bunger, P. C. \& Settles, H. E. Intimal musculature of the lower anterior spinal artery. Spine, 20:2073-9, 1995.

Puchades-Orts, A.; Nombela-Gomez, M. \& Ortuño-Pacheco, G. Variation in form of circle of Willis: some anatomical and embryological considerations. Anat. Rec., 185:11923, 1976.

Simionescu, N. \& Simionescu, M. O Sistema cardiovascular. In: Weiss L, Greep RO, eds. Histologia. Rio de Janeiro, Guanabara Koogan, 1981. pp 311-61.

Song, S. H. \& Roach, M. R. A morphological comparison of aortic elastin from five species as seen with the scanning electron microscope. Acta Anat., 123:45-50, 1985.
Viegas, K. A.; Orsi, A. M.; Matheus, S. M. M.; Francia-Farje, L.A.; Orsi, D. C. \& Mello, J.M. Características estructurales de la aorta del conejo (Oryctolagus cuniculus). Rev. Chil. Anat., 19:131-7, 2001.

Willekes, C.; Brands, P. J.; Willigers, J. M.; Hoeks, A. P. G. \& Reneman, R. S. Assessment of local differences in intima-media thickness in the human common carotid artery. J. Vasc. Res., 36: 222-8, 1999.

Wolinsky, H. \& Glagov, S. A. A lamellar unit of aortic medial structure and function in mammals. Circulation Res., 20: 99-111, 1967.

Correspondence to:

Prof. Dr. Antonio Marcos Orsi

Instituto de Biociências

Departamento de Anatomia

Distrito de Rubiäo Júnior $s / n$

CEP 18618-000

Botucatu-SP

BRASIL

Email:anatomia@ib6.unesp.br

Received: 01-02-2006

Accepted: 11-03-2006 